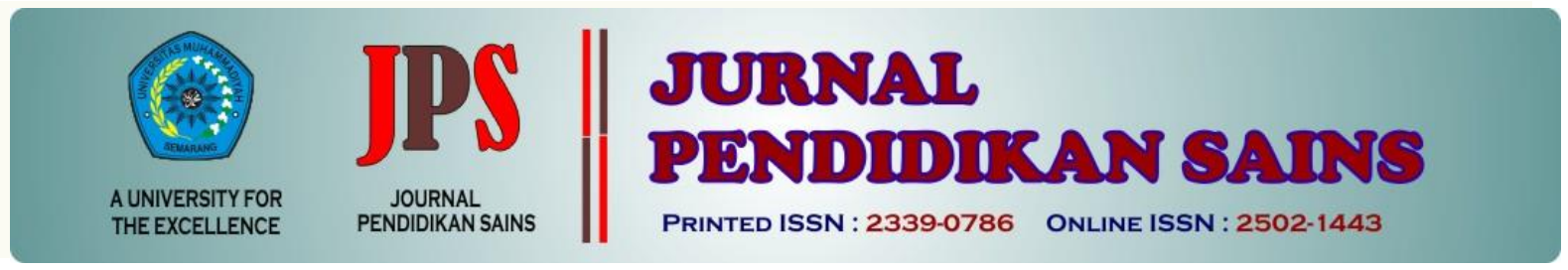

http://jurnal.unimus.ac.id/index.php/JPKIMIA

\title{
PEMANFAATAN ISU SOSIO-SAINTIFIK TRADISI MENGINANG SEBAGAI KONTEKS BELAJAR IPA SMP
}

\author{
Oleh: Riva Ismawati, Arief Budi Wicaksono \\ Jurusan MIPA, Fakultas Keguruan dan Ilmu Pendidikan, Universitas Tidar
}

\begin{tabular}{|c|c|}
\hline Article & \\
\hline : 2019-05-31 & \multirow{5}{*}{$\begin{array}{l}\text { This study aims to examine the socio-scientific issues of the betel } \\
\text { chewing tradition so that it can be used as a context for learning } \\
\text { science lessons in junior high school. The research conducted is } \\
\text { qualitative research with a case study approach. The population was } \\
\text { residents of Genito Village, Windusari Subdistrict, Magelang District } \\
\text { who still carried out the tradition of betel chewing. The research } \\
\text { sample was determined using cluster random sampling technique and } \\
\text { selected } 4 \text { respondents. The instruments used in the study are interview } \\
\text { guidelines and observation guidelines. The results showed that the } \\
\text { betel chewers believed that betel chewing could strengthen the teeth. } \\
\text { Unfortunately, betel chewers do not maintain oral hygiene so that the } \\
\text { activities of the chewing can have a negative impact. The socio- } \\
\text { scientific issue of the tradition of betel chewing can be built as a } \\
\text { context for junior high school science learning activities. }\end{array}$} \\
\hline & \\
\hline $2019-08-30$ & \\
\hline ocio-scient & \\
\hline & \\
\hline
\end{tabular}

\section{Pendahuluan}

Perkembangan IPTEK yang cepat di berbagai bidang kehidupan bertujuan untuk meningkatkan kualitas hidup manusia. Namun demikian, beberapa dampak negatif bermunculan seiring dengan kemajuan IPTEK seperti pemanasan global, krisis energi, pencemaran serta kerusakan lingkungan sekitar. Sains sebagai dasar perkembangan IPTEK harus mampu memberikan solusi terhadap dampak negatif yang ditimbulkan.

Sains dibagi menjadi 4 dimensi yang kemudian dipahami sebagai hakekat sains (nature of science/NOS). Ke empat dimensi tersebut adalah science as a way of thinking, science as a way of of investigating, science as a body of knowledge, science and its interactions with technology and society (Chiapetta \& Koballa, 2010). Lederman et al.
(2013) menyatakan bahwa NOS mengacu pada epistimologi pengetahuan yaitu pengetahuan sebagai cara mengetahui atau nilai dan keyakinan yang menjadi sifat pengembangan pengetahuan ilmiah.

Lederman, Lederman, \& Antink (2013) menyebutkan unsur NOS adalah (1) perbedaan antara pengamatan dan kesimpulan. Pengamatan adalah pernyataan deskriptif tentang fenomena alam yang dapat diamati langsung oleh indera. Kesimpulan adalah pernyataan tentang fenomena yang merupakan hasil dari menjelaskan dan menduga mengenai hal yang diamati (pernyataan tidak langsung oleh indera). (2) Perbedaan hukum ilmiah dan teori ilmiah. Hukum merupakan pernyataan atau deskripsi mengenai fenomena yang dapat diamati, sedangkan teori adalah kesimpulan dari penjelasan mengenai fenomena yang diamati. (3) pengetahuan ilmiah didasarkan

*Corresponding Author:

$\begin{array}{ll}\text { Nama } & \text { : Riva Ismawati } \\ \text { Lembaga } & \text { : Universitas Tidar } \\ \text { Email } & \text { : rivaismawati@untidar.ac.id }\end{array}$


pada pengamatan alam serta melibatkan imajinasi dan kreativitas manusia.

Pengetahuan ilmiah bersifat subjektif. (5) Sains sebagai aktivitas manusia dipraktekkan dalam konteks budaya yang lebih luas dan para ilmuwan adalah produk dari budaya. (6) Pengetahuan ilmiah tidak bersifat mutlak.

Pembelajaran sains akan berlangsung secara efektif jika ada pemahaman terhadap proses dan hakikat sains (NOS) serta mampu melakukan inkuiri ilmiah. Sementara itu, integrasi antara NOS dengan inkuiri ilmiah secara eksplisit dapat mengembangkan literasi sains (Lederman, Lederman, \& Antink, 2013). Strategi pembelajaran perlu diubah ketika seorang pengajar bermaksud mengajarkan inkuiri ilmiah dengan menyertakan NOS. Strategi pembelajaran yang semula hanya menyajikan sains sebagai kumpulan pengetahuan (body of knowledge) diubah menjadi strategi pembelajran yang menyajikan sains sebagai usaha manusia (human endevour) yang menghasilkan pengetahuan tentang alam semesta bersifat empiris konsisten secara internal namun belum sempurna (Rahayu, 2014).

Pembelajaran yang dilaksanakan di kelas hendaknya bertujuan untuk mewujudkan pembelajaran sains yang menghasilkan lulusan yang nantinya menjadi masyarakat yang berliterasi sains. Oleh karena itu, penting untuk memasukkan isu sosio-saintfik dalam kegiatan belajar mengajar di kelas. Isu sosio-saintifik adalah topik atau isu yang hidup secara sosial, memiliki komponen ilmiah, serta bersinggungan dengan bidang disiplin lain (politik, ekonomi, dan etika). Selain itu, isu sosio-saintifik juga melibatkan evaluasi aspek moral dan etika (Evagorou, Jimenezaleixandre, \& Osborne, 2012).

Isu sosio-saintifik menjadi semakin penting dalam bidang pendidikan sains karena berfungsi sebagai konteks belajar mengajar yang baik, yang memungkinkan siswa untuk memahami pentingnya sains dalam kehidupan sehari-hari dan mengembangkan kemampuan untuk menjadi individu yang kritis atas informasi ilmiah (Kolsto, 2001). Selain itu, isu sosio-saintifik juga mendorong partisipasi aktif siswa dalam diskusi, memberkan kerangka kerja untuk memahami konten ilmiah dan sifat sains, dan membantu mengembangkan keterampilan berfikir tingkat tinggi (HOTS), seperti berfikir kritis dan argumentasi (Evagorou et al., 2014; Zeidler \& Nichols, 2009).

Konteks pembelajaran meliputi segala sesuatu yang berada dilingkungan sekitar yang dapat berupa fisik, sosial, institusional, dan personal yang mempengaruhi proses belajar mengajar. Dalam pembelajaran yang berkonteks, hakikat sains (NOS) dikaitkan dengan topik tertentu (Rahayu, 2015).

Menginang merupakan tradisi mengunyah bahan-bahan pinang, kapur, dan gambir yang dibungkus dalam daun sirih. Para pengunyah sirih percaya bahwa kegiatan menginang dapat menjadikan gigi sehat dan kuat. Namun, kondisi dilapangan menunjukkan para pengunyah sirih kurang menjaga kebersihan mulut. Mulut merupakan salah satu organ pencernaan pada manusia yang perlu dijaga kebersihannya agar tidak menimbulkan penyakit. Berdasarkan uraian diatas, diperlukan upaya untuk mengkaji isu sosiosaintifik tradisi menginang sehingga dapat digunakan sebagai konteks belajar IPA SMP.

\section{Metode Penelitian}

Jenis Penelitian

Penelitian ini merupakan penelitian kualitatif dengan pendekatan studi kasus.

Waktu dan Tempat Penelitian

Penelitian dilaksanakan pada bulan Februari-Maret 2019 di Desa Genito, Kecamatan Windusari, Kabupaten Magelang.

Target/Subjek Penelitian

Populasi dalam penelitian ini adalah warga Desa Genito yang masih melakukan kegiatan menginang. Pengambilan sampel pada penelitian ini menggunakan teknik cluster random sampling. Dalam penelitian ini dipilih 4 responden sebagai sampel (R1, R2, R3, R4)

Intrumen, dan Teknik Pengumpulan Data

Intrumen yang digunakan dalam penelitian ini adalah pedoman wawancara dan pedoman observasi. Instrumen yang digunakan kemudian divalidasi oleh ahli. Teknik pengumpulan data dilakukan melalui dua cara yaitu wawancara dan observasi langsung di lapangan. Triangulasi dilakukan dengan 
Jurnal Pendidikan Sains (JPS) Vol 7 No.2 Oktober (2019) 123-128

mewawancarai beberapa warga untuk mendapatkan informasi yang lengkap.

Teknik Analisis Data

Data yang diperoleh kemudian diverifikasi, diintepretasikan, dan disusun sebagai konteks belajar. Selain itu, data yang diperoleh juga dibandingkan dengan fakta ilmiah.

\section{Hasil Penelitian dan Pembahasan}

Menginang merupakan tradisi yang dilakukan secara turun menurun. Pada saat sekarang ini, menginang masih dilakukan oleh orang tua saja dan sudah ditinggalkan oleh orang muda. Para pengunyah sirih masih mempertahankan kebiasaan menginang. Mereka tidak kesulitan untuk mendapatkan bahan-bahan untuk menginang. Bahan menginang sangat mudah ditemukan di pasar dengan harga yang sangat terjangkau.

Menginang merupakan tradisi masyarakat dengan komposisi dasar daun sirih, pinang, gambir, kapur dan tembakau. Komposisi tersebut dibungkus dalam daun sirih yang kemudian dikunyah. Masyarakat pengunyah memiliki alasan tersendiri mengapa mereka mengunyah sirih (Iptika, 2014). Semua responden dalam penelitian menyampaikan alasan menginang karena mereka percaya menginang dapat memperkuat gigi. Hal ini bersesuaian dengan hasil penelitian Flora, Taylor \& Rahman (2012). Flora, Taylor \& Rahman (2012) mengemukakan alasan imigran dari Asia Selatan di Inggris mengunyah sirih pinang karena memberikan rasa yang menyegarkan, sebagai makan ringan, membantu memperkuat gigi dan gusi.

Menginang dapat memperkuat gigi dimungkinkan karena sifat antibakteri dari bahan menginang yang digunakan. Semua responden menyampaikan bahwa bahan untuk menginang adalah daun sirih, gambir, kapur, dan tembakau untuk menyusur. Adapun bahan tambahan seperti kayu manis merupakan selera masing-masing.

Daun sirih yang digunakan untuk menginang mengandung minyak atsiri golongan terpenoid dan memiliki aktifitas antibakteri terhadap Streptococcus mutans (Rizkita, Cahyono, \& Mursiti, 2017). Katekin dalam gambir dapat menghancurkan sel membrane bakteri Streptococcus mutans melalui interaksinya dengan peptida bakteri (Pambayun, et al., 2008). Sementara itu, kapur akan menghasilkan ion $\mathrm{OH}^{-}$yang akan menyebabkan terjadinya denaturasi protein, kerusakan DNA dan membran sitoplasma bakteri (Siquera, 2001). Tembakau mengandung bahan aktif golongan fenol berupa flavonoid, golongan alkaloid berupa nikotin, golongan saponin berupa steroid, dan juga miyak atsiri berupa terpenoid yang berperan sebagai antibakteri dan antijamur (Fathiazad, et al., 2010). Namun, kepercayaan menginang dapat memperkuat gigi ternyata berlawanan dengan hasil observasi di lapangan. Diketahui bahwa gigi responden sudah tidak utuh lagi, bahkan ada responden yang giginya sudah habis tetapi masih juga melakukan kegiatan menginang. Selain itu, gigi responden juga teramati berwarna coklat kehitaman. Hasil tersebut bersesuaian dengan penelitian yang telah dilakukan oleh Iptika (2014) yaitu kondisi gigi masyarakat Sentul dengan kebiasaan mengunyah sirih pinang tidaklah bagus yaitu adanya karies gigi, gigi tidak utuh, gigi berwarna hitam, dan gigi tanggal.

Dua responden memiliki frekuensi menginang sebanyak 6-10 kali sedangkan dua responden lain menyatakan sering dan tidak terhitung frekuensi menginang dalam satu harinya. Penelitian sebelumnya menyebutkan bahwa kebiasaan menginang dalam waktu lama, frekuensi menginang lebih dari 10 kali sehari, dan tidak memperhatikan kebersihan mulut dan gigi dapat menyebabkan kanker rongga mulut (Rizduan, 2009). Hal ini disebabkan kapur yang digunakan sebagai bahan nginang dapat meningkatkan $\mathrm{pH}$ air liur menjadi 10 dan dapat memicu terbentuknya oksigen reaktif (radikal bebas). Selanjutnya, radikal bebas akan memicu pertumbuhan sel yang bersifat karsinogenik apabila dikonsumsi dengan bahan menginang lainnya (Auluck, et al., 2009; Rizduan, 2009; Shah, Chaturvedi, \& Vaishampayan, 2012). Daun sirih muda kaya akan safrole yang bersifat karsinogenik. Sementara itu, eugenol yang merupakan polifenol utama menginang bersifat sitotoksik terhadap fibroblast mukosa bukal dengan menurunkan tingkat ATP selular dan peroksidasi lipid (Rizduan, 2009; Shah, Chaturvedi, \& Vaishampayan, 2012). Tembakau mengandung senyawa hidrokarbon 
polisiklik aromatik, aldehid, amin aromatik, dan nitosamin yang juga bersifat toksik. Senyawa dalam tembakau tersebut menyebabkan kerusakan DNA karena ketidakseimbangan antara aktivasi dan detosifikasi karsinogen (Shah, Chaturvedi, \& Vaishampayan, 2012).

Rongga mulut merupakan salah satu organ pencernaan manusia. Menjaga kebersihan gigi merupakan salah satu upaya untuk menjaga kesehatan sistem pencernaan. Hasil penelitian menunjukkan bahwa responden masih belum menjaga kebersihan mulut. Para responden tidak membersihkan mulut setelah menginang, hanya berkumur sebelum makan, dan menggosok gigi hanya pada saat mandi. Iptika (2014) menyampaikan bahwa kebiasaan menggosok gigi sudah tergantikan dengan kebiasaan mengunyah sirih. Proses mengunyah sirih diakhiri dengan menyusur yaksi menggosok-nggosokkan gumpalan tembakau pada gigi. Menyusur diyakini sebagai sebagai pengganti menggosok gigi karena fungsinya untuk membersihkan gigi. Pengunyah sirih yang tidak rajin membersihkan gigi, dalam periode jangka panjang gigi mereka akan berubah warna hitam (Rooney, 1995). Perubahan warna gigi menjadi hitam disebabkan oleh stain (noda gigi) yaitu deposit berpigmen pada permukaan gigi (Khalisa, Adhani, \& Arifin, 2016). Stain teramati pada gigi responden penelitian dimana gigi berwarna coklat kehitaman

Masyarakat percaya bahwa menginang dapat memperkuat gigi. Namun, observasi dilapangan dan hasil penelitian sebelumnya menunjukkan hasil yang berlawanan. Fakta ini dapat digunakan sebagai sumber belajar mata pelajaran IPA bagi siswa SMP pada materi pokok sistem pencernaan pada manusia. Berikut adalah pembelajaran yang dapat disusun berdasarkan isu sosio-saintifik tradisi menginang.

Tabel 1. Kegiatan Pembelajaran Disusun Berdasarkan Isu Sosio-saintifik Tradisi Menginang.

\begin{tabular}{|c|c|c|c|}
\hline $\begin{array}{l}\text { Kompetensi } \\
\text { Dasar }\end{array}$ & $\begin{array}{l}\text { Materi } \\
\text { Pokok }\end{array}$ & $\begin{array}{l}\text { Submateri } \\
\text { Pokok }\end{array}$ & Pembelajaran \\
\hline \multirow{5}{*}{$\begin{array}{l}\text { Menganalisis } \\
\text { sistem } \\
\text { pencernaan pada } \\
\text { manusia dan } \\
\text { memahami } \\
\text { gangguan yang } \\
\text { berhubungan } \\
\text { dengan sistem } \\
\text { pencernaan, serta } \\
\text { upaya menjaga } \\
\text { kesehatan sistem } \\
\text { pencernaan }\end{array}$} & \multirow{5}{*}{$\begin{array}{l}\text { Sistem } \\
\text { pencernaan } \\
\text { pada } \\
\text { manusia }\end{array}$} & \multirow{5}{*}{$\begin{array}{l}\text { Upaya } \\
\text { menjaga } \\
\text { kesehatan } \\
\text { sistem } \\
\text { pencernaan }\end{array}$} & $\begin{array}{l}\text { 1. Siswa dalam kelompok mendiskusikan } \\
\text { kebiasaan menginang pada orang tua }\end{array}$ \\
\hline & & & $\begin{array}{l}\text { 2. Siswa dalam kelompok mendiskusikan } \\
\text { dampak positif dan negatif menginang }\end{array}$ \\
\hline & & & $\begin{array}{l}\text { 3. Siswa dalam kelompok mendiskusikan } \\
\text { senyawa aktif antibakteri dalam bahan } \\
\text { menginang }\end{array}$ \\
\hline & & & $\begin{array}{l}\text { 4. Siswa dalam kelompok mendiskusikan } \\
\text { senyawa karsinogen dan toksik dalam } \\
\text { bahan menginang }\end{array}$ \\
\hline & & & $\begin{array}{l}\text { 5. Siswa dalam kelompok mendiskusikan } \\
\text { kebiasaan pengunyah sirih yang } \\
\text { menggantikan kegiatan menggosok gigi } \\
\text { dengan menyusur }\end{array}$ \\
\hline
\end{tabular}

Pemanfaatan isu sosio-saintifik tradisi menginang dalam kegiatan belajar mengajar memungkinkan siswa untuk memahami pentingnya sains dalam kehidupan nyata, membangun kemampuan untuk berfikir kritis dan berargumentasi.

\section{Simpulan dan Saran}

Simpulan

Tradisi menginang dipercaya oleh masyarakat dapat memperkuat gigi. Hal tersebut dimungkinkan karena sifat antibakteri dalam bahan-bahn menginang. Namun, kebiasaan buruk pengunyah sirih yang tidak menjaga kebersihan mulut menyebabkan 
timbulnya dampak negatif dari kegiatan menginan. Fakta dan realita pada tradisi menginang dapat digunakan sebagai konteks kegiatan pembelajaran pada pelajaran IPA SMP pada materi pokok sistem pencernaan pada manusia.

Saran

Diperlukan penelitian lebih lanjut mengenai pemanfaatan dan pengembangan bahan ajar berdasarkan isu sosio-saintifik tradisi menginang terhadap hasil belajar, keterampilan berfikir kritis, dan keterampilan beragumentasi siswa.

\section{Ucapan Terima Kasih}

Penulis mengucapkan kepada Lembaga Penelitian, Pengabdian kepada Masyarakat dan Penjaminan Mutu Pendidikan (LPPM-PMP) Universitas Tidar yang telah mendanai penelitian ini.

\section{Daftar Pustaka}

Auluck, A., Hislop, G., Poh, C., Zhang, L., \& Rosin, M. P. (2009). Areca nut and betel quid chewing among South Asian immigrants to Western countries and its implications for oral cancer screening. Rural and remote health, 9(2), 1118.

Chiappetta, E. L. \& Koballa, T. R. Jr. (2010). Science instruction in the middle and secondary schoo ( $7^{\text {th }}$ ed.). New York: Pearson Education, Inc.

Evagorou, M., Albe, V., Angelides, P., Couso, D., Chirlesan, G., Evans, R. H., ... \& Nielsen, J. A. (2014). Preparing preservice science teachers to teach socioscientific (SSI) argumentation. Science Teacher Education, 69(39-48).

Evagorou, M., Jimenez-Aleixandre, M. P., \& Osborne, J. (2012). 'Should we kill the grey squirrels?'A study exploring students' justifications and decisionmaking. International Journal of Science Education, 34(3), 401-428.

Fathiazad, F., Delazar, A., Amiri, R., \& Sarker, S. D. (2010). Extraction of flavonoids and quantification of rutin from waste tobacco leaves. Iranian Journal of Pharmaceutical Research, 222-227.

Flora, M. S., Mascie-Taylor, C. G. N., \& Rahman, M. (2012). Betel quid chewing and its risk factors in Bangladeshi adults. WHO South-East Asia Journal of Public Health, 169.

Iptika, A. (2014). Keterkaitan kebiasaan dan kepercayaan mengunyah sirih Pinang dengan kesehatan gigi. Jurnal Masyarakat, Kebudayaan dan Politik, 3, 64-69.

Khalisa, E., Adhani, R., \& Arifin, S. (2016). Hubungan kebiasaan merokok dengan pembentukan stain (noda gigi) pada pasien di poli gigi RSUD Ratu Zalecha Martapura. Dentino, 1(1), 27-31.

Lederman, N. G., Lederman, J. S., \& Antink, A. (2013). Nature of science and scientific inquiry as contexts for the learning of science and achievement of scientific literacy. International Journal of Education in Mathematics, Science and Technology, 1(3).

Pambayun, R., Gardjito, M., Sudarmadji, S., \& Rahayu, K. (2008). Sensitivity of gram positive bacteria in catechins extracted from gambier (Uncaria Gambir [Roxb.]). Agritech, 28/4, 174-179.

Rahayu, Sri. 2014. Revitalisasi Scientific Approach dalam Kurikulum 2013 untuk Meningkatkan Literasi Sains: Tantangan dan Harapan. Seminar Nasional Kimia dan Pembelajarannya 2014.

Rahayu, S. (2015). Meningkatkan Profesionalisme Guru dalam Mewujudkan Literasi Sains Siswa melalui Pembelajaran Kimia/IPA Berkonteks Isu-Isu Sosiosaintifik (Socioscientific Issues). Keynote paper disampaikan dalam Semnas Pendidikan Kimia \& Sains Kimia di Fakultas Pendidikan MIPA FKIP Universitas Negeri Cendana, 8.

Ridzuan, N. B. (2009). Kanker rongga mulut disebabkan oleh kebiasaan menyirih. Medan: Skripsi. FakultasKedokteran Gigi Universitas Sumatera Utara. 
Rizkita, A. D., Cahyono, E., \& Mursiti, S. (2017). Isolasi dan Uji Antibakteri Minyak Daun Sirih Hijau dan Merah Terhadap Streptococcus mutans. Indonesian Journal of Chemical Science, 6/3, 279-286.

Rooney, D. F. (1995). Betel Chewing in South-East Asia. centre National de la Recherche Scientifique (CNRS). Lyon.

Shah, G., Chaturvedi, P., \& Vaishampayan, S. (2012). Arecanut as an emerging etiology of oral cancers in
India. Indian journal of medical and paediatric oncology: official journal of Indian Society of Medical \& Paediatric Oncology, 33(2), 71.

Siqueira, J. F. (2001). Strategies to treat infected root canals. CDA, 29(12), 825-838.

Zeidler, D. L., \& Nichols, B. H. (2009). Socioscientific issues: Theory and practice. Journal of Elementary Science Education, 21(2), 49. 